\title{
Meta-analysis of the energy and protein requirements of hair sheep raised in the tropical region of Brazil
}

\author{
A. P. Oliveira ${ }^{1}$ \\ E. S. Pereira ${ }^{1}$ \\ S. Biffani ${ }^{2}$ \\ A. N. Medeiros ${ }^{3}$ \\ A. M. A. Silva ${ }^{4}$ \\ R. L. Oliveira ${ }^{5}$ \\ M. I. Marcondes 6 \\ A. M. A. Silva |
}

${ }^{1}$ Department of Animal Science, Universidade Federal do Ceará, Fortaleza, Ceará, Brazil

${ }^{2}$ Istituto di Biologia e Biotecnologia Agraria, Consiglio Nazionale delle Ricerche, Lodi, Italia

${ }^{3}$ Department of Animal Science, Universidade Federal da Paraíba, Areia, Paraíba, Brazil

${ }^{4}$ Rural Health and Technology

Center, Universidade Federal de Campina

Grande, Patos, Paraíba, Brazil

${ }^{5}$ Department of Animal Science, Universidade Federal da Bahia, Salvador, Bahia, Brazil

${ }^{6}$ Department of Animal Science, Universidade Federal de Viçosa, Viçosa, Minas Gerais, Brazil

\section{Correspondence}

Marcos Inácio Marcondes, Department of Animal Science, Universidade Federal de Viçosa, Viçosa, Minas Gerais, Brazil. Email: marcosinaciomarcondes@gmail.com

\section{Summary}

The objective of this study was to estimate, through mathematical models, energy and protein requirements for maintenance and gain of hair sheep raised in the tropical region of Brazil. To determine the equation parameters, a meta-analysis of seven independent experiments of nutrient requirements was performed, comprising a total of 243 experimental units (animals), which were conducted under tropical conditions, using hair sheep in growing and finishing phases and endowed of the following quantitative data for each animal: body weight (BW), empty body weight (EBW), average daily gain (ADG), empty body gain (EBG), heat production (HP), metabolizable energy intake (MEI), retained energy (RE), metabolizable protein intake (MPI) and body protein content. The regression equations generated were as follows: for Net Energy for maintenance, $\left(\mathrm{NE}_{m}\right): \operatorname{LogHP}\left(\mathrm{MJ} \mathrm{EBW}^{-0.75} \mathrm{day}^{-1)}=-0.6090( \pm 0.07470)+0.5149( \pm 0.07216) \times \mathrm{MEI}_{\left(\mathrm{MJ} \mathrm{EBW}^{-0.75} \mathrm{day}^{-1}\right)}\right.$; for Net Energy for gain, $\left(\mathrm{NE}_{\mathrm{g}}\right): \quad \operatorname{LogRE}_{\left(\mathrm{MJ} \mathrm{EBW}^{-0.75} \mathrm{day}^{-1}\right)}=0.03084( \pm 0.05334)+$ $0.8455( \pm 0.04355) \times \operatorname{LogEBG}_{(\mathrm{kg} / \mathrm{day})}$; for Metabolizable Protein for maintenance, $\left(\mathrm{MP}_{\mathrm{m}}\right)$ : $\mathrm{MPI}_{(\mathrm{g} / \text { day })}=24.8470( \pm 7.3646)+560.28( \pm 99.6582) \times \mathrm{EBG}_{(\mathrm{kg} / \text { day })} ;$ for Net Protein for gain, $\quad\left(\mathrm{NP}_{\mathrm{g}}\right): \quad \mathrm{NP}_{\mathrm{g}(\mathrm{kg} / \mathrm{day})}=0.1941 \times \mathrm{EBW}_{(\mathrm{kg})}^{-0.1058}$. The $\mathrm{NE}_{\mathrm{m}}$ requirement was $0.246 \mathrm{MJ} \mathrm{EBW}^{-0.75} \mathrm{day}^{-1}$. The metabolizable energy for maintenance requirement was $0.391 \mathrm{MJ} \mathrm{EBW}^{-0.75}$ day $^{-1}$. Considering an $\mathrm{ADG}$ of $100 \mathrm{~g}$, the $\mathrm{NE}_{\mathrm{g}}$ requirement ranged from 0.496 to $1.701 \mathrm{MJ} /$ day for animals with $\mathrm{BW}$ ranging from 10 to $40 \mathrm{~kg}$ respectively. The efficiencies of use of the metabolizable energy for maintenance and gain were 0.63 and 0.36 respectively. The $\mathrm{MP}_{\mathrm{m}}$ requirement was $3.097 \mathrm{~g} \mathrm{EBW}^{-0.75} \mathrm{day}^{-1}$. Considering an $\mathrm{ADG}$ of $100 \mathrm{~g}$, the $\mathrm{NP}_{\mathrm{g}}$ requirement ranged from 12.4 to $10.5 \mathrm{~g} /$ day for animals with $\mathrm{BW}$ ranging from 10 to $40 \mathrm{~kg}$ respectively. The total metabolizable energy and protein requirements were lower than those reported by the NRC and AFRC systems. Thus, our results support the hypothesis that nutrient requirements of hair sheep raised in tropical regions differ from wool sheep raised in temperate regions. Therefore, the use of the equations designed in this study is recommended.

\section{KEYWORDS}

meat sheep, nutrient requirements, prediction equations 


\section{1 | INTRODUCTION}

The hair sheep is important in many production systems in developing countries. Its economic importance, which varies between regions, is the ability to convert forage or agro-industrial by-products into meat, fibre, skin and milk (Gutierrez-A, 1986). Despite its importance, information on nutrient requirements of these animals is still scarce. For this reason, we conducted a meta-analysis of the raw data from studies conducted in Brazil, which used the genotypes, Santa Ines, Morada Nova and Brazilian Somalis, to improve estimates of the nutrient requirements of hair sheep raised in the tropics, and to serve as a basis for future studies. In addition, these data are important to compose a larger database and thus to contribute to nutrition studies on small ruminants.

At present, the recommendations of the United States' National Research Council (NRC, 2007) are used in Brazil to formulate diets. However, the equations proposed by the NRC (2007) were primarily developed from wool sheep raised in temperate climate regions. Salah, Sauvant, and Archimède (2014) performed a meta-analysis of 590 publications to estimate energy and protein requirements of sheep, goats and growing cattle raised in areas of tropical climate and concluded that energy and protein requirements of ruminants raised in tropics are greater when compared to international systems like NRC, ARC, INRA and AFRC. One of the reasons to justify this difference is that, under conditions of high temperatures, the energy required to dissipate body heat significantly increases (CSIRO, 2007). The changes in energy requirements for maintenance and dry matter intake are the primary effects of the interaction between an animal and its environment, while the effects on energy requirements for production is a secondary effect (Fox \& Tylutki, 1998). According to NRC (2007), the effects of extreme cold or heat conditions on metabolizable protein requirements are not well understood. Tropical genotypes were not selected for muscle deposition, thereby depositing more fat than temperate genotypes and therefore, the energy cost per kg of gain might be greater (Early, Mahgoub, \& Lu, 2001). Therefore, we understand that nutrient requirements of hair sheep raised in the tropics differ from those of wool sheep raised in temperate regions. Thus, there is a critical need to assess the energy and protein requirements of these animals for production under tropical conditions worldwide.

Independent studies of nutrient requirements of hair sheep have primarily been performed in tropical regions. However, there are, in general, significant differences among studies (Azevêdo, Valadares Filho, Pina, Chizzotti, \& Valadares, 2010), resulting in inconclusive results. Thus, only through meta-analysis, it is possible to control the various effects observed across studies and to develop equations for prediction of general requirements of these animals.

Therefore, the objective of this study was to estimate energy and protein requirements for maintenance and gain of hair sheep raised in the tropical region of Brazil from a meta-analysis of studies conducted with hair sheep until the present moment. We hypothesize that nutrient requirements of hair sheep raised in tropics differ from those recommended by traditional committees on nutrient requirements for sheep (AFRC, 1993; NRC, 2007).

\section{2 | MATERIALS AND METHODS}

The approval of the ethics committee on animal use was not necessary in this study because the data were collected from previously published sources.

\section{1 | Inclusion criteria for studies}

Only studies containing information on individual animals, animals fed at maintenance levels and animals fed at least two levels above maintenance were included. Furthermore, only experiments conducted with hair sheep raised in the tropical region of Brazil that contained the following quantitative data on each animal were included: body weight (BW), empty body weight (EBW), average daily gain (ADG), empty body gain (EBG), heat production (HP), metabolizable energy intake (MEI), retained energy (RE), metabolizable protein intake (MPI) and body protein content (BPC).

The database was compiled from the results of seven studies, comprising a total of 243 animals and 28 treatments (Table 1). Currently, there are few studies of nutrient requirements of hair sheep available, and the raw data are often inaccessible. Therefore, this study has used raw data of only seven studies. The results from Nascimento Júnior (2010) were not included in the calculations of energy and protein requirements for maintenance because of lack of information on $\mathrm{MEI}$ and MPI. A descriptive analysis of the variables used in the metaanalysis is given in Table 2. The statistical significances of the effects of sex, genotype and feeding system could not be assessed because of the insufficient number of replicates and therefore must be accessed in a future study.

\section{2 | Variable estimates}

The EBW and body composition of the reference animals, slaughtered at the beginning of the experiments, were used to estimate the EBW and initial body composition of the remaining animals, slaughtered at the end of the experiments, within each study. The body energy content (BEC) was calculated based on body protein content (BPC) and on body fat content (BFC), according to the equation recommended by the $\operatorname{ARC~(1980):~} \mathrm{BEC}_{(\text {Mcal })}=\left(5.6405 \times \mathrm{BPC}_{(\mathrm{kg})}\right)+\left(9.3929 \times \mathrm{BFC}_{(\mathrm{kg})}\right)$. The MEI (MJ EBW ${ }^{-0.75}$ day $^{-1}$ ) was estimated from total digestible nutrients (TDN), assuming that $1 \mathrm{~kg}$ of consumed TDN provides $4.4 \mathrm{Mcal}$ of digestible energy (NRC, 2000) and that $82 \%$ of the digestible energy corresponds to the metabolizable energy (Cannas, Tedeschi, Fox, Pell, \& Van Soest, 2004). The MEI was estimated form TDN because not all studies had data from gas and urinary losses. To convert the energy, expressed in Mcal, into MJ, the values of HP, MEl and RE were multiplied by 4.184 . The daily RE (MJ) was assessed based on the difference between the final and initial body energy divided by the number of days of the corresponding experimental period. The daily HP (MJ) 


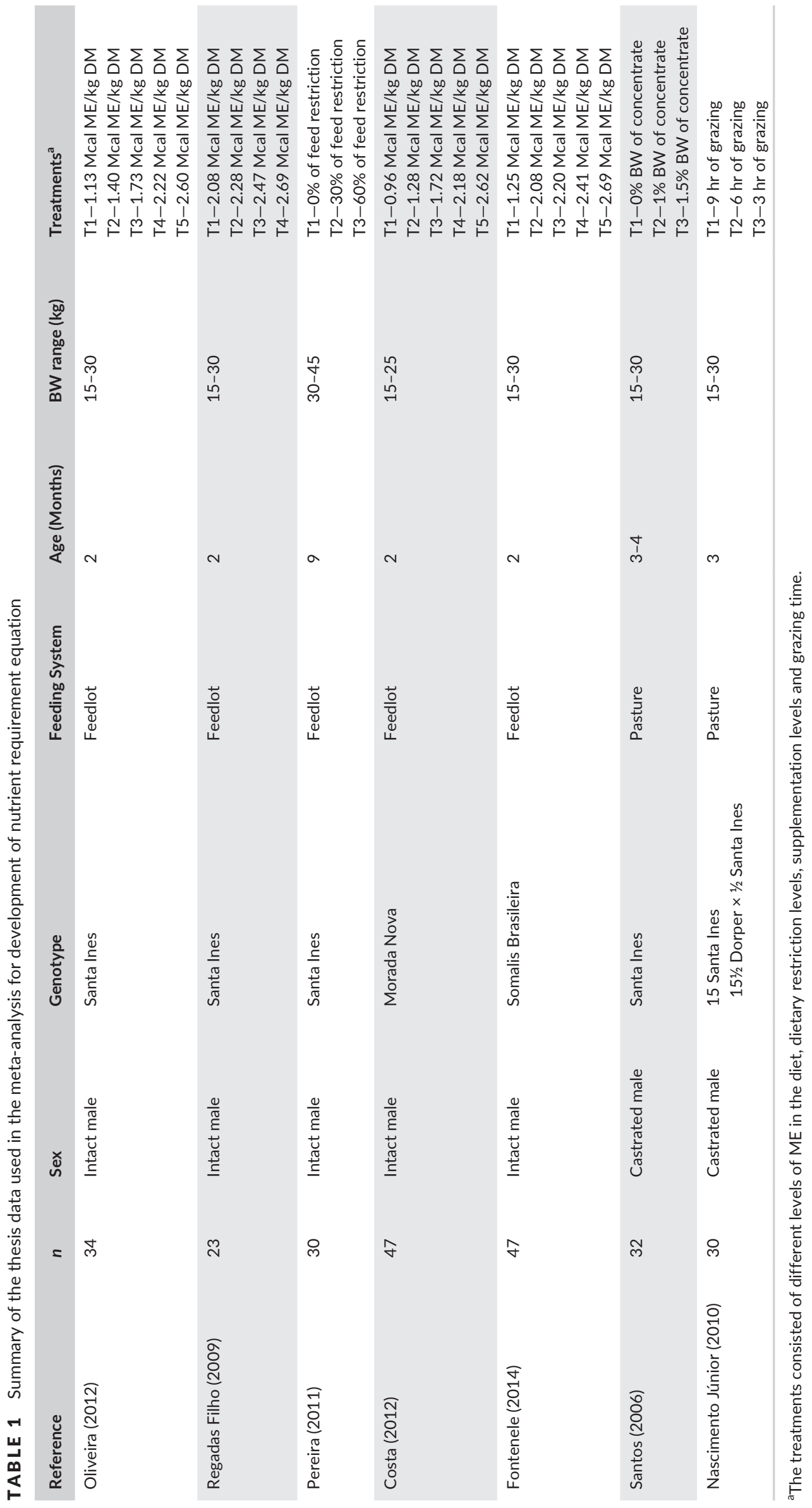


WI LEY-

\begin{tabular}{|lrrrrr|}
\hline Variable & \multicolumn{1}{l}{ n } & Minimum & Maximum & Mean & Standard deviation \\
\hline BW, kg & 243 & 10.12 & 47.34 & 24.61 & 7.66 \\
\hline EBW, kg & 243 & 6.34 & 37.86 & 19.15 & 6.76 \\
\hline EBW $^{0.75}, \mathrm{~kg}$ & 198 & 4.23 & 14.16 & 8.02 & 1.92 \\
\hline ADG, kg/day & 165 & 0.01 & 0.37 & 0.13 & 0.06 \\
\hline EBG, kg/day & 165 & 0.00 & 0.32 & 0.10 & 0.05 \\
\hline MEl, MJ/day & 174 & 1.53 & 24.23 & 6.59 & 3.00 \\
\hline RE, MJ/day & 198 & -1.80 & 5.80 & 1.26 & 0.93 \\
\hline HP, MJ/day & 171 & 1.04 & 21.76 & 5.33 & 2.53 \\
\hline MPI, g/day & 173 & 16.02 & 159.69 & 78.34 & 35.39 \\
\hline PBC, kg & 243 & 1.08 & 8.37 & 3.04 & 1.15 \\
\hline DMI, g/day & 173 & 263.12 & $1,405.72$ & 688.27 & 215.52 \\
\hline
\end{tabular}

TABLE 2 Descriptive statistics of the variables used in the meta-analysis

BW, body weight; EBW, empty body weight; $\mathrm{EBW}^{0.75}$, metabolic empty body weight; ADG, average daily gain; EBG, empty body gain; MEI, metabolizable energy intake; RE, retained energy; HP, heat production; MPI, metabolizable protein intake; PBC, protein body content; DMI, intake dry matter.

was estimated based on the difference between daily MEI (MJ) and daily RE (MJ).

The EBW ( $\mathrm{kg}$ ) and EBG (kg/day) were estimated according to linear regression Equations 1 and 2 respectively:

$$
\begin{aligned}
& \mathrm{EBW}=\beta_{0}+\beta_{1} \times \mathrm{BW}, \\
& \mathrm{EBG}=\beta_{0}+\beta_{1} \times \mathrm{ADG},
\end{aligned}
$$

where $\mathrm{EBW}=$ empty body weight $(\mathrm{kg}) ; \mathrm{BW}=$ body weight $(\mathrm{kg})$; $\mathrm{EBG}=$ empty body gain ( $\mathrm{kg} /$ day); $\mathrm{ADG}=$ average daily gain; and $\beta_{0}$ and $\beta_{1}$ are the coefficients of the regression equations. Both performance and reference animals were considered to develop the EBW equation, but only performance animals were used to develop the EBG equation because growth pattern of performance animals differs from that of animals fed at maintenance levels.

The requirement of net energy for maintenance $\left(\mathrm{NE}_{\mathrm{m}}\right.$, MJ EBW ${ }^{-0.75}$ day $^{-1}$ ) was assumed as the antilog of the intercept of the linear regression of the logarithm of $\mathrm{HP}$ as a function of $\mathrm{MEI}$ (Equation 3), as suggested by Lofgreen and Garrett (1968). All data sets, except the reference group, were included for this calculation.

$$
\operatorname{LogHP}=\beta_{0}+\beta_{1} \times \mathrm{MEI},
$$

where $\mathrm{HP}=$ heat production $\left(\mathrm{MJ} \mathrm{EBW}^{-0.75} \mathrm{day}^{-1}\right)$; $\mathrm{MEI}=$ metabolizable energy intake ( $\mathrm{MJ} E B W^{-0.75} \mathrm{day}^{-1}$ ); and $\beta_{0}$ and $\beta_{1}$ are the coefficients of the linear regression equation of the logarithm of HP as a function of $\mathrm{MEI}$.

The requirement of metabolizable energy for maintenance $\left(\mathrm{ME}_{\mathrm{m}}, \mathrm{MJ} \mathrm{EBW}^{-0.75}\right.$ day $\left.^{-1}\right)$ was calculated by the iterative method in Equation 3, which corresponds to the point at which the HP is equal to the MEI.

The efficiency of use of metabolizable energy for maintenance $\left(k_{m}\right)$, in turn, was obtained from the ratio between $\mathrm{NE}_{\mathrm{m}}$ and $\mathrm{ME}_{\mathrm{m}}$ requirements, as proposed by Garrett (1980).
Considering the same group of animals, but excluding the study of Nascimento Júnior (2010), the efficiency of use of metabolizable energy for gain ( $k_{\mathrm{g}}$; Equation 4 ) was evaluated as described by Galvani et al. (2014), in which the slope of the linear regression between RE and the metabolizable energy intake for gain $\left(\mathrm{MEI}_{\mathrm{g}}\right)$ represents the efficiency of use of metabolizable energy for gain $\left(k_{\mathrm{g}}\right)$ :

$$
\mathrm{RE}=\beta_{0}+\beta_{1} \times \mathrm{MEI}_{\mathrm{g}}
$$

where RE = retained energy $\left(\mathrm{MJ} \mathrm{EBW}^{-0.75} \mathrm{day}^{-1}\right) ; \mathrm{MEI}_{\mathrm{g}}=$ metabolizable energy intake for gain(MJ EBW ${ }^{-0.75}$ day $^{-1}$ ); and $\beta_{0}$ and $\beta_{1}$ are the coefficients of the linear regression equation of $\mathrm{RE}$ as a function of $\mathrm{MEI}_{\mathrm{g}}$.

The Equation 5 was used to estimate the net energy for gain $\left(\mathrm{NE}_{\mathrm{g}}\right.$, MJ EBW ${ }^{-0.75}$ day $\left.^{-1}\right)$ :

$$
\operatorname{LogRE}=\beta_{0}+\beta_{1} \times \log E B G,
$$

where $\mathrm{RE}=$ retained energy $\left(\mathrm{MJ} \mathrm{EBW}^{-0.75}\right.$ day $\left.^{-1}\right)$; $\mathrm{EBG}=$ empty body gain ( $\mathrm{kg} /$ day); and $\beta_{0}$ and $\beta_{1}$ are the coefficients of the linear regression equation of the logarithm of RE as a function of the logarithm of EBG. Only performance animals were included in this model.

The MPI was obtained from the sum of truly digestible microbial CP (TDMCP), and the digestible rumen undegradable protein intake (DRUPI; Equation 6). The TDMCP was obtained from the product between the total digestible nutrients intake (TDNI) and the efficiency of microbial synthesis of $76.2 \mathrm{~g}$ of microbial CP per $\mathrm{kg}$ TDNI. This value was obtained from the mean value of the control treatments evaluated in studies of sheep and goat raised in tropical regions (Argôlo et al., 2010; Carvalho et al., 2010; Fonseca et al., 2006; Pereira, 2013). TDMCP was obtained by multiplying CPmic by 0.64 , assuming that CPmic is constituted of $80 \%$ of amino acids and has intestinal digestibility of $80 \%$ (NRC, 2000). The DRUPI was calculated subtracting the ruminal degradable protein (RDP; assuming that $90 \%$ of the RDP corresponds to microbial $\mathrm{CP}$ and the other $10 \%$ correspond to losses by ammonia) of total crude protein intake, and multiplying the result by 
TABLE 3 Equations developed from the meta-analysis to estimate the nutrient requirements of hair sheep raised in tropical regions

\begin{tabular}{|c|c|c|c|c|}
\hline & Equations & $n$ & $\sigma^{2}$ & $p$-Value \\
\hline 2 & $E B G_{(k g / \text { day })}=-0.01875( \pm 0.004128)+0.9671( \pm 0.02799) \times A D G$ & 129 & 0.000117 & $<.0001$ \\
\hline 4 & 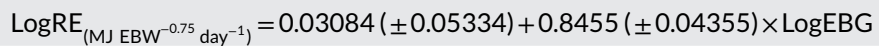 & 144 & 0.006987 & $<.0001$ \\
\hline 5 & $\left.\mathrm{RE}_{(\mathrm{MJ} \mathrm{EBW}}{ }^{-0.75} \mathrm{day}^{-1}\right)=0.3628( \pm 0.05637) \times \mathrm{MEI}_{\mathrm{g}}$ & 152 & 0.002981 & .0013 \\
\hline 7 & $\mathrm{NP}_{\mathrm{g}(\mathrm{kg} / \mathrm{day})}=0.1941 \times \mathrm{EBW}^{-0.1058}$ & 146 & 14.6145 & .0003 \\
\hline
\end{tabular}

EBW, empty body weight; BW, body weight (kg); EBG, empty body gain; ADG, average daily gain (kg/day); HP, heat production; MEl, metabolizable energy

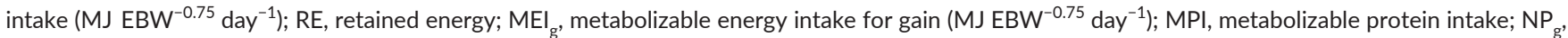
requirement of net protein for gain of $1.0 \mathrm{~kg}$ EBW.

0.80 , which is the fixed value of digestibility of RUP in the small intestine (NRC, 2000):

$$
\mathrm{MPI}=(\mathrm{TDNI} \times 76.2 \times 0.64)+((\mathrm{CPI}-(\mathrm{CPmic} \times 1.11)) \times 0.80),
$$

where $\mathrm{MPI}=$ metabolizable protein intake (g/day); TDNI = total digestible nutrients intake (kg/day); CPI = crude protein intake (g/day); $\mathrm{CPmic}=$ microbial crude protein (g/day).

The requirement of metabolizable protein for maintenance $\left(\mathrm{MP}_{\mathrm{m}}\right.$, $\mathrm{gEBW}^{-0.75} \mathrm{day}^{-1}$ ) was calculated from the ratio between the intercept of Equation 7 and the mean metabolic EBW, as proposed in NRC (2000):

$$
\mathrm{MPI}=\beta_{0}+\beta_{1} \times \mathrm{EBG},
$$

where $\mathrm{MPI}=$ metabolizable protein intake (g/day); $\mathrm{EBG}=$ empty body gain (kg/day); and $\beta_{0}$ and $\beta_{1}$ are the coefficients of the linear regression equation of MPI as a function of EBG. Both performance (animals fed above maintenance) and maintenance animals were considered. Another alternative for the estimation of the $\mathrm{MP}_{\mathrm{m}}$ requirement is to use the ADG; however, the evaluation of EBG reduces errors associated with the effects of gastrointestinal filling (Marcondes, Gionbelli, Valadares Filho, Chizzotti, \& Paulino, 2010).

The requirement of net protein for gain of $1 \mathrm{~kg} \mathrm{EBW}\left(\mathrm{NP}_{\mathrm{g}}, \mathrm{kg} / \mathrm{day}\right)$ was estimated deriving the regression equation of the logarithm of body protein content as a function of logarithm of EBW (Equation 8):

$$
N P_{g}=\beta_{1} \times 10^{\beta_{0}} \times \mathrm{EBW}^{\left(\beta_{1}-1\right)}
$$

where $\mathrm{NP}_{\mathrm{g}}$ = requirement of net protein for gain of $1 \mathrm{~kg} \mathrm{EBW} \mathrm{(kg/day);}$ EBW $=$ empty body weight $(\mathrm{kg})$; and $\beta_{0}$ and $\beta_{1}$ are the coefficients of the linear regression equation of the logarithm of body protein content as a function of logarithm of EBW. Both performance and reference animals were included in this model.

To convert the $\mathrm{NP}_{\mathrm{g}}$ requirement into the corresponding requirement of metabolizable protein for gain (MPg), an efficiency of use of metabolizable protein for gain of 0.70 was adopted, as recommended by the NRC (2007). We chose to use the value suggested by the NRC (2007) as the value estimated by our database was biologically improbable (0.18), which suggests that further studies must be conducted to better understand the efficiency of use of metabolizable protein for gain.

\section{3 | Statistical analysis}

The meta-analysis was performed as suggested by St-Pierre (2001). A random coefficients model was adopted, considering the study as a random effect, and including the possibility of covariance between the slope and the intercept. Three types of variance-covariance structures were tested: variance components (VC), unstructured (UN), and heterogeneous autoregressive (ARH (1)). The Akaike information criteria (AIC) of these variance-covariance structures were assessed to define the best model.

The covariance parameter was considered to be non-zero when the $p$-value was less than .10. The outliers were removed when the studentized residuals were greater than 2 or less than -2 . Significance levels of .05 and .20 were imposed for fixed and random effects respectively. All statistical procedures were performed using the PROC MIXED procedure of the statistical analysis software SAS version 9.2 (SAS Inst. Inc., Cary, NC).

The general statistical model employed for data analysis was (Equation 9):

$$
Y_{i j}=\beta_{0}+\beta_{1} X_{i j}+s_{i}+b_{i} X_{i j}+e_{i j}
$$

where $Y_{i j}=$ dependent variable $Y$ observed at level $j$ of the independent variable $X$ in study $i ; \beta_{0}=$ overall intercept for all study data (fixed effect); $\beta_{1}=$ overall regression coefficient of $Y$ on $X$ for all study data (fixed effect); $X_{i j}=$ observed value $j$ of the independent variable $X$ in study $i ; s_{i}=$ random effect of study $i$ on intercept $\beta_{0} ; b_{i}=$ random effect of study $i$ on the regression coefficient $\beta_{1}$ in study $i ; e_{i j}=$ unexplained random residual error.

\section{3 | RESULTS}

\subsection{EBW and EBG}

Regression Equations 1 and 2 (Table 3) were developed to estimate the EBW and EBG from BW and ADG respectively. These variables are essential to assess nutrient requirements of animals. 


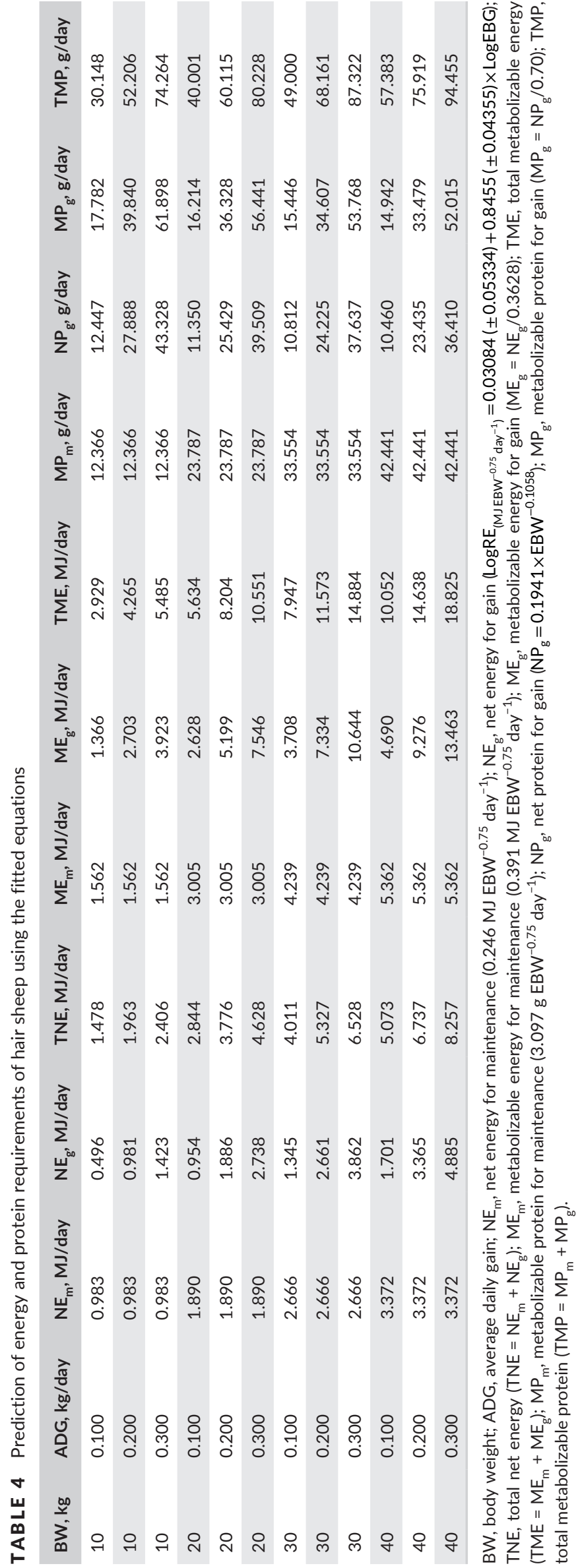

\section{2 | Energy requirements}

The $\mathrm{NE}_{\mathrm{m}}$ requirement, calculated from Equation 3 (Table 3), was $0.246 \mathrm{MJ} \mathrm{EBW}^{-0.75} \mathrm{day}^{-1}$. The $\mathrm{ME}_{\mathrm{m}}$ requirement was $0.391 \mathrm{MJ} \mathrm{EBW}^{-0.75} \mathrm{day}^{-1}$, with an efficiency of use of $\mathrm{ME}_{\mathrm{m}}$ of 0.63 . Considering an ADG of $100 \mathrm{~g}$, the $\mathrm{NE}_{\mathrm{g}}$ requirement, calculated from Equation 4 (Table 3), ranged from 0.496 to $1.701 \mathrm{MJ} /$ day for animals with BW ranging from 10 to $40 \mathrm{~kg}$ respectively (Table 4). The $k_{\mathrm{g}}$, estimated from Equation 5 (Table 3), was 0.36. The ratio between the $\mathrm{NE}_{\mathrm{g}}$ and $k_{\mathrm{g}}$ provides an estimate of the requirement of metabolizable energy for gain $\left(\mathrm{ME}_{\mathrm{g}}\right.$; Table 4). Total nutrient requirements were calculated using the factorial method, as used in the majority of international systems. The analysis revealed that total metabolizable energy (TEM) requirement, expressed as $\mathrm{MJ} /$ day, increases with increases in animal BW and ADG (Table 4).

\section{3 | Protein requirements}

The $\mathrm{MP}_{\mathrm{m}}$ requirement, calculated from Equation 6 (Table 3), was $3.097 \mathrm{~g} \mathrm{EBW}^{-0.75} \mathrm{day}^{-1}$. Considering an ADG of $100 \mathrm{~g}$, the $\mathrm{NP}_{\mathrm{g}}$ requirement, calculated from Equation 7 (Table 3), ranged from 12.4 to $10.5 \mathrm{~g}$ /day for animals with BW ranging from 10 to $40 \mathrm{~kg}$ respectively. The TMP requirement, expressed in $\mathrm{g} / \mathrm{day}$, increased with increases in BW and ADG of animals (Table 4).

\section{DISCUSSION}

\subsection{Energy requirements}

The $\mathrm{NE}_{\mathrm{m}}$ includes the energy required for muscle activity, tissue turnover and involuntary metabolic processes (NRC, 1985). The mean value of $\mathrm{NE}_{\mathrm{m}}$ obtained in our study of $0.246 \mathrm{MJ} \mathrm{EBW}^{-0.75}$ day $^{-1}$ (maximum and minimum values were 0.383 and $0.158 \mathrm{MJ} \mathrm{EBW}^{-0.75}$ day $^{-1}$ respectively) was greater than that reported by Gonzaga Neto et al. (2005), which reported a $\mathrm{NE}_{\mathrm{m}}$ of $0.222 \mathrm{MJ} \mathrm{EBW}^{-0.75} \mathrm{day}^{-1}$ in a study with Morada Nova non-castrated lambs. This variation may be attributed to differences between genotypes, as our database was composed basically by Santa Ines genotype, which has early-maturing compared to Morada Nova genotype. Rodrigues et al. (2016), in turn, in a study with non-descript breed hair lambs (intact males, castrated males and females), reported a $\mathrm{NE}_{\mathrm{m}}$ of $0.285 \mathrm{MJ} \mathrm{EBW}^{-0.75}$ day $^{-1}$ for the three genders. Converting the $\mathrm{NE}_{\mathrm{m}}$ requirement obtained in our study into a fasting body weight base $\left(\mathrm{BWf}^{0.75}\right)$, the obtained value was $0.210 \mathrm{MJ} B W f^{-0.75} \mathrm{day}^{-1}$. This value is lower than the value reported by Galvani, Pires, Kozloski, and Wommer (2008) of $0.247 \mathrm{MJ} \mathrm{BWf}^{-0.75}$ day $^{-1}$ in a study on non-castrated cross-bred Texel sheep (wool sheep). The value of $\mathrm{NE}_{\mathrm{m}}$ obtained in our study was even lower than the value recommended by the NRC (2007) and AFRC (1993), which suggests a non-adjusted $\mathrm{NE}_{\mathrm{m}}$ of 0.259 and $0.289 \mathrm{MJ} \mathrm{BWf}^{-0.75}$ day $^{-1}$ (without adjustment for activity) respectively. This variation may be attributed to environmental differences between tropical and temperate regions, as hypothesized in our study. The climate in the Brazilian Northeast is the semi-arid, characterized 
by low rainfall (less than $800 \mathrm{~mm} /$ year) and high temperatures with little variability during the year (average annual temperature above $27^{\circ} \mathrm{C}$; Pereira, 2005). Starling, Silva, Negrão, Maia, and Bueno (2005) observed a significant and negative correlation between environmental temperature and thyroid hormone secretion (the secretion of thyroxine- $\mathrm{T}_{3}$ and triiodothyronine- $\mathrm{T}_{4}$ decreased with an increase in environmental temperature) in a study of Corriedale sheep (wool sheep). Thyroid hormones have a strong effect on metabolism, and their increased secretion causes the metabolic rate to increase, while reductions in secretion levels are associated with a decrease in metabolic rate (Guyton, 1996). Thus, reductions in the metabolic rates of tissues occur when the effective environmental temperature exceeds the upper critical temperature of the thermoneutral zone (i.e., heat stress) because of the reduced secretion of $T_{3}$ and $T_{4}$ hormones, resulting in decreased energy required for maintenance. Furthermore, according to the NRC (2000), productivity is compromised in environments with higher temperatures because feed intake is reduced and voluntary feed intake is, in general, positively correlated with fasting heat production (Chilliard \& Bocquier, 2000). Thus, we may conclude that the energy requirement for maintenance is reduced in environments with higher temperatures, which explains the lower $\mathrm{NE}_{\mathrm{m}}$ requirement observed in this study when compared to NRC (2007) and AFRC (1993). Acclimatization, which consists of adaptive changes in response to climate change, including behavioural and physiological changes, could also justify this change in $\mathrm{NE}_{\mathrm{m}}$ demand. It is noteworthy that the animals differ greatly in their behavioural and physiological responses to adapt to a specific environment. In this context, differences among genotypes are particularly evident (NRC 2000). Using an approach of $\mathrm{ME}_{\mathrm{m}}$ requirement at the full BW base, Salah et al. (2014) reported that small tropical ruminants have $\mathrm{ME}_{\mathrm{m}}$ requirement higher than the tempered small ruminants (259.06 vs. $243.4 \mathrm{~kJ} / \mathrm{BW}$ ). However, when converting the $\mathrm{ME}_{\mathrm{m}}$ requirement obtained in our study (0.391 $\mathrm{MJEBW}^{-0.75} \mathrm{day}^{-1}$ ) into a BW base, the value of $0.149 \mathrm{MJ} \mathrm{BW}^{-1}$ day $^{-1}$ is observed, which is well below the value proposed by Salah et al. (2014). Information about genotype, handling and performance of the animals is not described in the article of Salah et al. (2014); therefore, it is possible that differences observed between our results and those of Salah et al. (2014) might be associated to these factors. Furthermore, we used individual raw data, which allow more effective control of the study effect, while Salah et al. (2014) used average data obtained from reviews, thesis and reports. Is noteworthy that the efficiency of use of $\mathrm{ME}_{\mathrm{m}}$ obtained in our study of 0.63 was close to those reported by the NRC (2007), Gonzaga Neto et al. (2005), Galvani et al. (2008) and Rodrigues et al. (2016) of $0.64,0.67,0.64$ and 0.69 respectively?

The rate and composition of gain, and nutrient use efficiencies must be known to determine the requirements for gain (NRC, 2007). In our study, $\mathrm{NE}_{\mathrm{g}}$ requirement varied with $\mathrm{BW}$ and $\mathrm{ADG}$ (Table 4). The requirements we obtained are lower than those recommended by the NRC (2007) for early-maturing animals with 4 months old. For instance, for an animal with a $20 \mathrm{~kg}$ of BW and ADG of $100 \mathrm{~g}$, the $\mathrm{NE}_{\mathrm{g}}$ requirement estimated by our study is $0.954 \mathrm{MJ} /$ day, whereas the $\mathrm{NE}_{\mathrm{g}}$ requirement estimated by the $\mathrm{NRC}$ (2007) is $1.925 \mathrm{MJ} /$ day.
In the Brazilian literature, values lower than ours have been reported by Galvani et al. (2008). Conversely, Gonzaga Neto et al. (2005) and Rodrigues et al. (2016) have reported values greater than those of this study. Variations in the methodology and/or biological variations may account for such differences. For instance, we have used the logarithm of the ER in function of the logarithm of EBG, while Gonzaga Neto et al. (2005) and Galvani et al. (2008) have used the logarithm of the $E R$ in function of the logarithm of EBW. The differences between genotypes regarding $\mathrm{NE}_{\mathrm{g}}$ requirement mainly resulted from differences in mature weights and fat distributions (Chizzotti, Tedeschi, \& Valadares Filho, 2008). Furthermore, the factors that affect $k_{\mathrm{g}}$ might also affect $\mathrm{NE}_{\mathrm{g}}$ requirements (Garrett, 1980). Therefore, these differences may also be due to differences in gain composition. The $k_{\mathrm{g}}$ value calculated in our study (0.36) was similar to that (0.38) reported by Gonzaga Neto et al. (2005). However, Galvani et al. (2008) proposed a $k_{\mathrm{g}}$ value of 0.47 , which explains the lower $\mathrm{NE}_{\mathrm{g}}$ requirement reported by these authors. The gain composition might be a key factor in determining $k_{\mathrm{g}}$, once the efficiency of use of ME for protein deposition ranges from $10 \%$ to $40 \%$, while the efficiency of use of ME for fat deposition ranges from $60 \%$ to $80 \%$ (Garrett, 1980).

The TME requirements obtained in our study were lower than the values reported by AFRC (1993) and NRC (2007). For instance, considering an animal with $20 \mathrm{~kg}$ of BW and ADG of $100 \mathrm{~g}$, the TME requirement obtained in our study was $5.6 \mathrm{MJ} /$ day (Table 4), while the AFRC (1993) and NRC (2007) systems reported values of 6.7 and 6.3 respectively. That would represent a reduction of $16.4 \%$ and $11.1 \%$, respectively, on TME for hair sheep raised in tropics when compared to wool sheep raised in temperate climate regions.

\subsection{Protein requirements}

The method used to assess the $\mathrm{MP}_{\mathrm{m}}$ in this study is based on animal growth instead of nitrogen balance (NRC, 2000). The most appropriate calculation uses MPI instead of the crude protein intake (CPI), because the CPI may generate estimation errors by failing to consider the biological value of crude protein or microbial protein synthesis (Marcondes et al., 2010), and metabolizable protein includes truly digestible amino acids absorbed in small intestine (AFRC, 1993). The $\mathrm{MP}_{\mathrm{m}}$ value calculated in this study (3.097 $\mathrm{g} \mathrm{EBW}^{-0.75} \mathrm{day}^{-1}$ ) is greater than the values reported by Gonzaga Neto et al. (2005), Galvani, Pires, Kozloski, and Sanchez (2009) and the AFRC (1993) of $2.08 \mathrm{~g} \mathrm{BW}^{-0.75} \mathrm{day}^{-1}$, $2.31 \mathrm{~g} \mathrm{BWf}^{-0.75} \mathrm{day}^{-1}$ and $2.19 \mathrm{~g} \mathrm{BW}^{-0.75}$ day $^{-}$respectively.

In our study, $\mathrm{NP}_{\mathrm{g}}$ requirement varies with the ADG. Our values are lower than the values suggested by Gonzaga Neto et al. (2005), which reported an $\mathrm{NP}_{\mathrm{g}}$ value of $22.02 \mathrm{~g} /$ day for an animal with a $20 \mathrm{~kg}$ of $\mathrm{BW}$ and ADG of $100 \mathrm{~g}$, while in our study, the value was of $11.35 \mathrm{~g} /$ day. This difference is mainly explained by the difference in mature weights of the animals. The animals studied by those authors were Morada Nova, a genotype considered as late-maturing. Early-maturing genotypes are expected to have lower net protein requirement than latematuring genotypes (Geay, 1984). Galvani et al. (2009) and Rodrigues et al. (2016) reported values similar to those determined in this study of 11.30 and $9.9 \mathrm{~g} /$ day, respectively, for the same animal type. 
The TMP requirement obtained in our study was lower than the values proposed by the AFRC (1993) and NRC (2007). For instance, the TMP value determined in our study for an animal with $20 \mathrm{~kg}$ of BW and ADG of $100 \mathrm{~g}$ was $40 \mathrm{~g} /$ day, while the corresponding value suggested by the AFRC (1993) for feedlot intact lambs is $64 \mathrm{~g} /$ day, and the value suggested by the NRC (2007) is $47 \mathrm{~g} /$ day. We believe the difference in genotypes the main factor accounting for this variation. The NRC (2007) system considers animals from wool genotypes. MacRae, Walker, Brown, and Lobley (1993) noted that the N wool level accounted for $11.5 \%$ of the total body $N$ of a $25 \mathrm{~kg}$ animal in a study with Suffolk-Finn Dorset lambs. Thus, the higher protein requirement reported by the NRC (2007) system might result from $N$ required for wool growth in the considered animals. The $N$ required for wool deposit, added to genotype and environmental effects, might respond this great difference observed for TMP.

Our results support the hypothesis that nutrient requirements of hair sheep raised in tropical climate regions are different from those recommend by NRC (2007) and AFRC (1993).Therefore, we recommend the values of $0.246 \mathrm{MJ} \mathrm{EBW}^{-0.75} \mathrm{day}^{-1}, 3.097 \mathrm{~g} \mathrm{EBW}^{-0.75} \mathrm{day}^{-1}$, 0.63 and 0.36 for $\mathrm{NE}_{\mathrm{m}}, \mathrm{MP}_{\mathrm{m}}, \mathrm{k}_{\mathrm{m}}$ and $k_{\mathrm{g}}$, respectively, for hair sheep raised in tropical regions. The database used in this study was not big enough to evaluate individual genotypes or sex effects on nutrient requirements; thus, further studies should be conducted to better estimate requirements of wool and hair sheep raised both on temperate and/or tropical regions.

\section{REFERENCES}

AFRC (1993). Energy and protein requirements of ruminants. Wallingford, CT: CAB International.

ARC (1980). The nutrient requirement of ruminant livestock. Technical review. Commonwealth Agricultural Bureaux, Farnham Royal.

Argôlo, L. S., Pereira, M. L. A., Dias, J. C. T., Cruz, J. F., Rei, J. D., \& Oliveira, C. A. S. (2010). Mesquite pod meal in diets of lactating goats: Ruminal parameters and microbial synthesis efficiency. Brazilian Journal of Animal Science, 39, 541-548.

Azevêdo, J. A. G., Valadares Filho, S. C., Pina, D. S., Chizzotti, M. L., \& Valadares, R. F. D. (2010). A meta-analysis of dry matter intake in Nellore- and Zebu-crossed cattle. Brazilian Journal of Animal Science, 39, 1801-1809.

Cannas, A., Tedeschi, L. O., Fox, D. G., Pell, A. N., \& Van Soest, P. J. (2004). A mechanistic model for predicting the nutrient requirements and feed biological values for sheep. Journal of Animal Science, 82, 149-169.

Carvalho, G. G. P., Garcia, R., Pires, A. J. V., Silva, R. R., Pereira, M. L. A., Viana, P. T., ... Pereira, T. C. J. (2010). Nitrogen balance, urea concentrations and microbial protein synthesis in goats fed diets containing sugar cane treated with calcium oxide. Brazilian Journal of Animal Science, 39, 2253-2261.

Chilliard, Y., \& Bocquier, F. (2000). Direct effects of photoperiod on lipid metabolism, leptin synthesis and milk secretion in adult sheep. In P. B. Cronjé (Ed.), Ruminant physiology digestion, metabolism, growth and reproduction (pp. 205-223). Wallingford, CT: CAB International.

Chizzotti, M. L., Tedeschi, L. O., \& Valadares Filho, S. C. (2008). A metaanalysis of energy and protein requirements for maintenance and growth of Nellore cattle. Journal of Animal Science, 86, 1588-1597.

Costa, M. R. G. F. (2012). Nutrient requirements of hair lambs and small ruminant nutrition system (RNSS) model validation. Thesis. Universidade Federal do Ceará, Fortaleza.
CSIRO (2007). Nutrient requirements of domesticated ruminants. Melbourne, VIC: CSIRO publishing.

Early, R. J., Mahgoub, O., \& Lu, C. D. (2001). Energy and protein utilization for maintenance and growth in Omani ram lambs in hot climates. I. Estimates of energy requirement and efficiency. Journal of Agricultural Science, 136, 451-459.

Fonseca, C. E. M., Valadares, R. F. D., Valadares Filho, S. C., Leão, M. I., Cecon, P. R., Rodrigues, M. T., ... Araújo, A. M. (2006). Microbial protein synthesis in lactating goats fed diets with increasing levels of dietary protein. Brazilian Journal of Animal Science, 35, 1169-1177.

Fontenele, R. M. (2014). Nutrient requirements of lambs of the Brazilian Somalis breed. Thesis. Universidade Federal do Ceará, Fortaleza.

Fox, D. G., \& Tylutki, T. P. (1998). Accounting for the effects of environment on the nutrient requirements of dairy cattle. Journal of Dairy Science, 81, 3085-3095.

Galvani, D. B., Pires, C. C., Kozloski, G. V., \& Sanchez, L. M. B. (2009). Protein requirements of Texel crossbred lambs. Small Ruminant Research, 81, 55-62.

Galvani, D. B., Pires, C. C., Kozloski, G. V., \& Wommer, T. P. (2008). Energy requirements of Texel crossbred lambs. Journal of Animal Science, 86, 3480-3490.

Galvani, D. B., Pires, A. V., Susin, I., Gouvêa, V. N., Berndt, A., Chagas, L. J., ... Tedeschi, L. O. (2014). Energy efficiency of growing ram lambs fed concentrate-based diets with different roughage sources. Journal of Animal Science, 92, 250-263.

Garrett, W. N. (1980). Factors influencing energetic efficiency of beef production. Journal of Animal Science, 51, 1434-1440.

Geay, Y. (1984). Energy and protein utilization in growing cattle. Journal of Animal Science, 58, 766-778.

Gonzaga Neto, S., Silva Sobrinho, A. G., Resende, K. T., Zeola, N. M. B. L., Silva, A. M. A., Marques, C. A. T., \& Leão, A. G. (2005). Body composition and nutrient requirements of protein and energy for Morada Nova lambs. Brazilian Journal of Animal Science, 34, 2446-2456.

Gutierrez-A, N. (1986). Economic constraints on sheep and goat production in developing countries. In V. M. Timon \& J. P. Hanrahan (Eds.), Small ruminant production in the developing countries (pp. 138-147). Bulgaria: Sofia.

Guyton, A. C. (1996). Medical physiology treatise (9th ed.). Rio de Janeiro: Guanabara Koogan.

Lofgreen, G. P., \& Garrett, W. N. (1968). A system for expressing net energy requirements and feed values for growing and finishing beef cattle. Journal of Animal Science, 27, 793-806.

MacRae, J. C., Walker, A., Brown, D., \& Lobley, G. E. (1993). Accretion of total protein and individual amino acids by organs and tissues of growing lambs and the ability of nitrogen balance techniques to quantitate protein retention. Animal Production Science, 57 237-245

Marcondes, M. I., Gionbelli, M. P., Valadares Filho, S. C., Chizzotti, M. L., \& Paulino, M. F. (2010). Nutrient requirements for beef cattle. In S. C. Valadares Filho, M. I. Marcondes, M. L. Chizzotti \& P. V. R. Paulino (Eds.), Nutrient requirements of pure and crossbred zebu (BR-CORTE) (pp. 113-134). Viçosa: Universidade Federal de Viçosa.

Nascimento Júnior, N. G. (2010). Performance, Carcass Characteristics and Nutrient Requirements for Protein and Energy for the Weight Gain of Santa Inês and $1 / 2$ Dorper X $1 / 2$ Santa Inês Lambs Grazing in the Semiarid Region. Dissertation. Universidade Federal de Campina Grande, Patos.

NRC (1985). Nutrient requirements of sheep (6th ed.). Washington, DC: Natl. Acad. Press.

NRC (2000). Nutrient requirements of beef cattle (7th ed.). Washington, DC: Natl. Acad. Press.

NRC (2007). Nutrient requirements of small ruminants. Washington, DC: Natl. Acad. Press.

Oliveira, A. P. (2012). Nutrient Requirements of Santa Ines Lambs with Body Weights Ranging from 14 to $28 \mathrm{~kg}$. Dissertation. Universidade Federal do Ceará, Fortaleza.

Pereira, J. C. C. (2005). Bioclimatology fundamentals applied to animal production. Belo Horizonte: FEPMVZ. 
Pereira, G. M. (2011). Energy and Protein Requirements of Santa Ines Rams in the Brazilian Semiarid Region. Dissertation. Universidade Federal de Campina Grande, Patos.

Pereira, M. W. F. (2013). Nutrient and nycterohemeral variables of diets with different fat sources in Santa Ines sheep. Dissertation. Universidade Federal do Ceará, Fortaleza.

Regadas Filho, J. G. L. (2009). Energy and Protein Requirements of Growing Santa Inês Sheep. Dissertation. Universidade Federal doCeará, Fortaleza.

Rodrigues, R. T. S., Chizzotti, M. L., Martins, S. R., Silva, I. F., Queiroz, M. A. A., Silva, T. S., ... Silva, A. M. A. (2016). Energy and protein requirements of non-descript breed hair lambs of different sex classes in the semiarid region of brazil. Tropical Animal Health Production, 48, 87-94.

Salah, N., Sauvant, D., \& Archimède, H. (2014). Nutrient requirements of sheep, goats and cattle in warm climates: A meta-analysis. Animal, 8, 1439-1447.

Santos, E. M. (2006). Estimated Intake and Nutrient Requirements of Protein and Energy for Sheep Grazing in the Semiarid. Dissertation. Universidade Federal de Campina Grande, Patos.

Starling, J. M. C., Silva, R. G., Negrão, J. A., Maia, A. S. C., \& Bueno, A. R. (2005). Seasonal variation of thyroid hormones and cortisol of sheep in a tropical environment. Brazilian Journal of Animal Science, 34, 2064-2073.

St-Pierre, N. R. (2001). Invited review: Integrating quantitative findings from multiple studies using mixed model methodology. Journal of Dairy Science, 84, 741-755.

\section{SUPPORTING INFORMATION}

Additional Supporting Information may be found online in the supporting information tab for this article.

How to cite this article: Oliveira AP, Pereira ES, Biffani S, et al. Meta-analysis of the energy and protein requirements of hair sheep raised in the tropical region of Brazil. J Anim Physiol Anim Nutr. 2017;00:1-9. https://doi.org/10.1111/jpn.12700 